\title{
Implementation and Educational Innovation of Structural Presumption Theory of Ika Valensia on Police Investigator's Speech Act
}

\author{
Ika Arifianti ${ }^{1}$, Fatur Rokhman ${ }^{2}$, Subyantoro ${ }^{2}$, Ida Zulaeha ${ }^{2}$ \\ ${ }^{1}$ Doctoral Program of Indonesian Language Education, Universitas Negeri Semarang, Indonesia \\ ${ }^{2}$ Graduate School, Universitas Negeri Semarang, Indonesia \\ Corresponding email: ikaarivianti@yahoo.co.id
}

\begin{abstract}
The novelty of this research is on the data collection of interrogations by investigators studied by reference to Levinson's (1985) theory of presumption. The results of this research became a new contribution in pragmatic and police studies. In presumption theory, this study focuses only on structural presumption in function categories. This study is the result of the research findings conducted by Ika Valensia, which is the development of the theory of Levinson. The interrogation process required qualified investigator. Normative legal approach consists of study on the principles of law which is related to legal research. The data sources of this study is the investigation report of criminal complaints in 2013 in cases of domestic violence conducted by members of the Police. The results of this study describes the realization of representative speech in the case of criminal complaints in Central Java Regional Police. This research can be a reference for further research in the Pragmatic study.
\end{abstract}

Keywords: Pragmatics, Structural Presumption, Ika Valensia’s Theory, Criminal Complaints

\section{Introduction}

Interrogation speech by investigators in criminal complaint case in Regional Police of the Central Java can be used as a pragmatic research object. In this study, Investigation \& Interrogation Report (BAP) is the source of data. The Regional Police of Central Java is a relevant place of research because it is the highest regional police institution which oversees several Departmental Police of the Republic of Indonesia resorts in a province. Each police institution from the Regional to sectoral police has the investigator as the main role to disclose a problem through INVESTIGATION \& INTERROGATION REPORT activities. Police investigators have authority in conducting interrogation activities against suspects, witnesses or expert witnesses. This is in accordance with CRIMINAL CODE on the rules of the investigator, namely Article 1 number 1 CRIMINAL CODE PROCEDURES

"The investigator is a police officer of the Republic of Indonesia or a certain civil servant officer who is specifically authorized by law to conduct an investigation."

Pragmatic is an interesting approach to examine the process of language INVESTIGATION \& INTERROGATION REPORT, because the manifestations of the human mind in the form of unpleasant speech can affect the lawlessness behaviors. Descriptive forms of human behavior that violate the law can have an effect on the crime. Such unpleasant behavior is included in the category of criminal complaint. Cases of criminal complaint are cases relating to defamation, slander, or other behaviors that are less favorable. If the victim feels disadvantaged in this case, the victim has the right to report to the police on the basis of existing evidence. Based on the report, the police summoned witnesses and suspects for further questioning. The information is filled and known as INVESTIGATION \& INTERROGATION REPORT (BAP). The role of this report is to disclose information from suspects, witnesses, or victims so that the problem becomes clear. This is done for law enforcement process in Indonesia. In this report, there is a linguistic element, which is a legal lecture in the pragmatic domain.

It is clear that the investigator's discourse in INVESTIGATION \& INTERROGATION REPORT contains the element of hegemony. Hegemony is a particular element capable of constructing universal demands. The process of state domination of society takes place through the ideological state apparatus which constructs a false consciousness in society and fortifies society from the formation of knowledge of the existence of exploitation and oppression. The notion of hegemony has been suggested by Gramsci (in Ritzer 2004: 100) which defines hegemony as a cultural leadership run by the ruling class. This concept is in contrary to the concept of hegemony run by legislative or executive power, or expressed by police interference. This phenomenon becomes worthy of research with pragmatic studies for the development of the scientific field of linguistics in Indonesia.

Rokhman (2005) conducted a study entitled Language Selection as a Status Control and Familiarity in a Diglossic Society: a Sociolinguistic Study in Banyumas. The results 
concluded that in social interaction in Banyumas, the speakers face a variety of speech partners with various backgrounds and conditions respectively. The conditions of the speech partners are, among others, related to the relationship of speakers and partner speeches, either vertically or horizontally.

The first dimension includes social status and second dimension of social distance. The speaker's assumption of these two dimensions will determine the accuracy of his choice of language. The relevance of this research with previous studies conducted by other researchers are both to do research on the field of language and data sources is in the form of speech.

Al-Qaderi and Umar (2015) with his research entitled: Conversational Implicature in Arabic: A Pragmatic Analysis of Applying Flouting the Maxims to the Yemeni Dialect and published in the International Journal of Education, examined the implications of scorn speech in Yemeni dialect Arabic. The study focuses on Gricean's theory of implicatures and applied to Arabic. Data collection was done by interviewing semi-structured 15 participants who spoke Yemen dialect. All interviews were recorded, transcribed, translated and interpreted. The research approach used was qualitative and quantitative approach. The analysis focused on violation of maxims in scoffing. The results of the study reveal that implicatures can be applied to Arabic, especially the Yemeni dialect and the maxim of quantity is most often violated. The relevance of the research is on use of the same theory of Grace in the process of data analysis.

Leech (in Wijana 1996: 3-4) states that pragmatics is a branch of language science that examines the use of language that is integrated with grammar consisting of phonology, morphology, syntax and semantics. Pragmatics is a branch of linguistics that is increasingly known today, although in about two decades ago this science was rarely or almost never mentioned by linguists.

Yule (2006: 46-51) states five types of presuppositions, namely (a) factive presupposition, (b) lexical presupposition, (c) structural presupposition, (d) non-factive presupposition, and (e) counter-factual presupposition.

Levinson (1978) states pragmatics is the study of language usage. Levinson divides the pragmatic meaning into five: (1) pragmatics is seen as a language study with the context, (2) pragmatics is a study of aspects of meaning not covered by semantic aspects; (3) pragmatics is a study of language with the underlying context of explanation of understanding or understanding of language, (4) pragmatics is the study of deixis (at least in part), implicature, presupposition, speech art, and aspect of discouse structure.

The formulation of the problem in this research is how the application of structural preformance theory by IkaValensia in interrogation speech of Police investigator? The purpose of this study is to describe the application of the theory of structural responsiveness of IkaValensia to the interrogative speech of Polri investigators. The benefits of this research are divided into two, namely theoretical and practical benefits. Theoretically, the results of this study are expected to contribute to the development of pragmatic studies related to the interrrogation characteristics of investigators whose data are sourced from INVESTIGATION \& INTERROGATION REPORT (BAP) in the case of criminal complaint in Regional Police of Central Java. This research can also be a source of literature in understanding and developing pragmatics for educators, researchers, and college students in a sustainable manner. The findings of this study in the form of new structural presupposition from IkaValensia can be a positive contribution in the field of education, as well as research. Practically this research is expected to add insight and knowledge about linguistics especially in Pragmatics. this study is also expected to contribute to the institution related linguistics as a treasure library in the development of pragmatic science.

\section{Method}

The methodological approach used in this research is descriptive-qualitative method. This approach is used because the data obtained is from INVESTIGATION \& INTERROGATION REPORTof expert witnesses in criminal complaint case from Regional Police of Central Java. The pragmatic review is the domain of applied science in the linguistic level that is worthy of research because it combines research in linguistics and law. Therefore,Pragmatics in its development can be a worthy study. Normative legal research consists of research on the principles of law. This normative law approach, related to legal research called legal research. This research includes field research and documentation study. Documentation study is a study conducted by collecting case-related cases and then proceed with the understanding of cases. Documents that are the subject of the research are INVESTIGATION \& INTERROGATION REPORT of criminal 
complaint case in 2013 at Regional Police of the Republic of Indonesia of Central Java.

This research data are in the form of complete text fragment of INVESTIGATION \& INTERROGATION REPORT taken during the interrogation process in the case of criminal complaint of Regional Police of the Republic of Indonesia of Central Java which has been classified according to the field of research. The source of this research data is the full text of investigator interrogation on suspect in INVESTIGATION \& INTERROGATION REPORT process in case of criminal complaint in Regional Police of Central Java. Secondary data in this research arereference books, documents and various laws and regulations related to the problem of the research.

There are three technique of data collecting: (1) reading technique, (2) nonparticipant observation technique, (3) advanced note technique. Data analysis is the process of organizing and sorting data into patterns, categories, and units of basic descriptions so that the theme can be found and can be formulated into working hypothesis.

\section{Result \& Discussion}

\section{A. Structural Presupposition with Functions of Asking Clarity}

(1) Do you know Prof. Dr. Edi Suryono, SH.,MH ? If you know, since when (have you known him) and in what relationship (INVESTIGATION \& INTERROGATION REPORT I Victim, Question No 05)

Fragment of Question (INVESTIGATION \& INTERROGATION REPORT I Victim, Question No. 05) submitted by the investigator "Do you know Prof. Dr. Edi Suryono, SH.,MH ? If you know, since when (have you known him) and in what relationship ... " is included in presupposition with the function of asking for structural clarity as it refers to the structure of the sentence and analyzed as a constant and conventional presupposition that the part of the structure has been assumed to be true to the word when referring to the answer of the victim "I do not know Prof. Dr. Edi Suryono SH MH".

Speech fragment INVESTIGATION \& INTERROGATION REPORT I Question no.06 is a structural question of the function of asking clarity.

(2)Is it true that after you met Mr. KRISBIYANTORO and Mr. HELMI, you met Mrs. MARYATI and Mrs. ARI ?, when and where were the meeting taking place? ...

(INVESTIGATION $\&$

INTERROGATION REPORT I Additional Victims I, Question No 05)
Part of utterence (Question No. 05) submitted by the investigator "Is it true that after you met Mr. KRISBIYANTORO and Mr. HELMI, you met Mrs. MARYATI and Mrs. ARI ?, when and where were the meeting taking place?... "is included in the structural presupposition with the function of the questioning because it refers to the sentence structure and is analyzed as a constant and conventional presupposition that the part of the structure has been assumed to be true to the word when and where it refers to the answer that it is not true that I have met $\mathrm{Mr}$. KRISBIYANTORO and Mr. HELMI, and I also never met Mrs. MARYATI and Mrs. ARI. The speech fragment in INVESTIGATION \& INTERROGATION REPORT I, additional questions II, no.05 is included in structural responses with questioning clarity functions.

(3) Do you know Mr. HELMY and Mr. KRISBIYANTORO ?, Since when and in what relationship? (INVESTIGATION \& INTERROGATION REPORT I Witness III Krisbiyantoro, Question No 09)

Speech fragment in INVESTIGATION \& INTERROGATION REPORT I Witness III Krisbiyantoro, Question No 09) The investigator submitted "Do you know $\mathrm{Mr}$. HELMY and Mr. KRISBIYANTORO ?, since when and in what relationship? ..." is included in structural presuppositions with the function of asking for clarity because the speech refers to the sentence structure and is analyzed as a constant and conventional presumption. The part of the structure has been assumed to be true in the word "when" refers to the answer of witness Witness III Krisbiyantoro which is meant by Mr. KRISBIYANTORO in the newspaper is my own. Yes, I have known Mr. HELMY since 2000; we are only friends and business patners.

Speech fragment INVESTIGATION \& INTERROGATION REPORT I question no.03 is included in structural presupposition with function of asking for clarity. live?"

(4) "... at that time Mrs Y ... where did she

(INVESTIGATION \& INTERROGATION REPORT 2 / Question No. 4)

In the speech fragment (No. 4) on (INVESTIGATION \& INTERROGATION REPORT 2) "... at that time Mrs Y ... where did she live?" is a Structural Presupposition with the function of asking for clarity, because in the sentence there is a question with the word" Where"; as a word conventionally interpreted as a question word. In this sentence the investigator assumes the truth about the place of residence and speech is explaining. 
Therefore, the statement is a Strultural Presupposition.

Speech fragment INVESTIGATION \& INTERROGATION REPORT I Question no.06 is a structuralpresupposition withfunction of asking clarity.

(5) "When and where have you been abandoned by your husband? Where? Since when?"

(INVESTIGATION

$\&$

INTERROGATION REPORT 2 / Question No. 5)

In Speech fragment (No. 5) on (INVESTIGATION \& INTERROGATION REPORT 2) "When and where have you been abandoned by your husband? Where? Since when? " is a structural Presupposition with the function of clarifying the clarity, because in the fragment there is a question word" When and Where "; the word is a word conventionally interpreted with a question word. In the fragment of the sentence the investigator assumes the truth about when and where her husband abandoned her and the fragment of the speech is explaining. Therefore, the splitting of the speech is a Structural Presupposition.

Speech fragment of INVESTIGATION \& INTERROGATION REPORT 3 questions no.06 is included in structural presupposition with function of asking clarity.

\section{B. Structural Presupposition with the Function of Asking Place and Time}

(1) Is it true that you have ever met Mr. KRISBIYANTORO and Mr. HELMI in one of the rooms?, and when did the meeting take place?

(INVESTIGATION

$\&$

INTERROGATION REPORT I Additional Victim I, Question No 04)

Questioning Question No. 04, Question No. 04) submitted by the investigator "Is it true that you have ever met Mr. KRISBIYANTORO and Mr. HELMI in one of the rooms?, and when did the meeting take place?..." is a structural presupposition with the function of asking the place and time as it refers to the structure of the sentence and it is analyzed as a constant and conventional presupposition. The part of the structure has been assumed to be true due to the word "when" which refers to the answer "I have never met and met face to face with the lord KRISBIYANTORO and master HELMI the ".

INVESTIGATION

INTERROGATION REPORT I, II supplementary, question no.04, is a structural presupossition with the function of asking time and place.
(2) When and where was the money handed over? When and where? by whom and who accepted it? for what purpose?...

(INVESTIGATION

\&

INTERROGATION REPORT I, Suspect, Question No 11e)

Question Question (INVESTIGATION \& INTERROGATION REPORT I Suspect, Question No 11e) submitted by the investigator "When and where is the money handed over? When and where? by whom and who is accepted? for what purposes? ... "is a structural presuppositions with the function of asking place and time as it refers to sentence structure and is analyzed as a constant and conventional presupposition and that the part of the structure has been assumed to be true due to the word" when and where "which refers to the answer of the suspect" I do not know about this, who knows this is the master of HARWINTO.

INVESTIGATION INTERROGATION REPORT I, the questionnaire no.29, is a structural presupposition wiht the function of asking time and place.

(3) Since when did you work in UNDIP Semarang? And (in what position) did you serveas ...

(INVESTIGATION

$\&$

INTERROGATION REPORT I Criminal Expert, Question No 05)

Question Question (INVESTIGATION \& INTERROGATION REPORT I, Criminal Officer, Question No. 05) submitted by the investigator "Since when did you work in UNDIP Semarang? And (in what position) did you serveas ...." isstructural presupposition with function of asking place and time as it refers to sentence structure and is analyzed as a constant and conventional presupposition that the part of the structure has been assumed to be true to the word when referring to the answer of the criminal expert I work in the Faculty of Law University Diponegoro since March 1991 and now has the functional position of Head Lector.

The discussion in this study uses the theory of Levinson (1978) which states that pragmatics is the study of language usage. Levinson divides the pragmatics into five views, namely (1) pragmatics is considered as a language study with the context, (2) pragmatics is a study of aspects of meaning not covered by semantic aspects, (3) pragmatics is a study of language with a context that underlies the explanation of understanding or understanding of language , (4) pragmatics is the study of the praxes (5) pragmatics is the study of deixis (at least in part), implicatur, presupposition, speech art, and aspect of 
discouse structure. This study focuses on the structural presupposition of IkaValensia theory with object of INVESTIGATION \& INTERROGATION REPORT in case of criminal complaint in Regional Police of the Republic of Indonesia of Central Java.

\section{Conclusion}

Interrogative power of investigators is a central study of this study. Pragmatic studies became the researcher's interest and choice, as some of the earlier researches related to investigators' interrogation processes in performing their duties as state apparatus were still limited. The renewal of this research is in the realm of research data collection, namely investigator's interrogation to suspects. The interrogation results were reviewed pragmatically, so that the results of this study became a new contribution in the world of linguistic and police research. The study which is the new finding in this study is the application of structural presupposition theory with the function category.

\section{Reference}

Al-Qaderi, Issa Ali Umar. 2015. Conversational Implicature in Arabic: A Pragmatic Analysis of Applying Flouting the Maxims to the Yemeni Dialect. International
Journal of Education. Vol 7 (6): 53-68.

http://macrothink.org/journal/index. php/ijl/article/view/8745

Bawengan. 2006. Penyidikan Perkara Pidana dan Teknik Interograsi. Jakarta: Pradny aPramita.

Brow, Penelope dan S.C. Levinson. 1978.

Universals in Language

Usage:Politness Pheomena

dalam Ester N.Goody (ed)

Question ang Politness.Cambrige University Press. Hal 56-342.

Leech. 2011. Principle of Pragmatics. Terj M.D.D.Oka.1993. Prinsip-prinsip Pragmatik. Jakarta; UI; London; Logman.

http://www.ijern.com/journal/2014/August -2014/48.pdf.

Rokhman, Fathur. 2005. "Kode Komunikatif dalam Interaksi Sosial Masyarakat Diglosik di Pedesaan: Kajian Sosiolinguistik di Banyumas". Jurnal Fenolingua (Online). Vol. 13 (2).

(Diakses pada tanggal 3 Maret 2018)

Wijana. 1996. Dasar-dasar Pragmatik. Yogyakarta: ANDI OFFSET. 